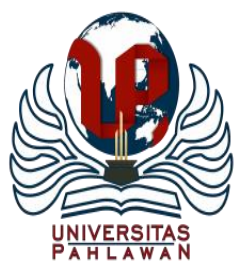

Jurnal Basicedu Volume 4 Nomor 2 April 2020 Hal. 453- 459

JURNAL BASICEDU

Research \& Learning in Elementary Education

https://jbasic.org/index.php/basicedu

\title{
PENGARUH KEPEMIMPINAN KEPALA SEKOLAH DAN DANA BOS TERHADAP PRESTASI GURU
}

Rita Armaiyetti ${ }^{1}$,Sufyarma Marsidin ${ }^{2}$, Hanif Alkadri ${ }^{3}$

Universitas Negeri Padang, Sumatera Barat, Indonesia ${ }^{1,2,3,}$

E-mail : : rita2017@gmail.com, sufyarma1954@ gmail.com, hanifalkadri@ fip.unp.ac.id ${ }^{4}$

\begin{abstract}
Abstrak
Tujuan penelitian ini untuk melihat pengaruh kepemimpinan kepala sekolah dan dana BOS terhadap prestasi guru di SD Negeri 61 Payakumbuh. Jenis penelitian adalah penelitian kuantitatif dengan korelasi. Populasinya adalah guru-guru di SD Negeri 61 Payakumbuh sebanyak 10 guru. Data penelitian dikumpulkan melalui melakukan pengamatan terhadap prilaku kepala sekolah terhadap guru. Berdasarkan Hasil penelitian yang diperoleh menunjukkan bahwa Terdapat kontribusi antara kepemimpinan kepala sekolah dengan prestasi guru di SD Negeri 61 Payakumbuh sebesar 8,5\% dan Terdapat kontribusi antara dana BOS dengan prestasi guru di SD Negeri 61 Payakumbuh sebesar 7,8\%. Dapat disimpulkan bahwa terlihat pengaruh kepemimpinan kepala sekolah dan dana BOS terhadap prestasi guru di SD Negeri 61 Payakumbuh.
\end{abstract}

Kata Kunci : Kepemimpinan Kepala Sekolah, Dana BOS, Prestasi Guru.

\begin{abstract}
The purpose of this study was to look at the influence of school principal leadership and BOS funds on teacher achievement in SD Negeri 61 Payakumbuh. This type of research is quantitative research with correlation. The population is 10 elementary school teachers in Payakumbuh State Elementary School. Research data were collected through observing the behavior of principals towards teachers. Based on the results of the study obtained showed that there was a contribution between the leadership of the school principal and the achievement of teachers in SD Negeri 61 Payakumbuh by $8.5 \%$ and there was a contribution between BOS funds and the achievement of teachers in SD Negeri 61 Payakumbuh by $7.8 \%$. It can be concluded that the influence of school principal leadership and BOS funds can be seen on teacher achievement in SD 61 Payakumbuh.
\end{abstract}

Keywords : Principal Leadership, BOS Funds, Teacher Achievements

@ Jurnal Basicedu 2020

$\triangle$ Corresponding author :

Address : Air Tawar Padang

Email : rita2017@gmail.com

ISSN 2580-3735 (Media Cetak)

Phone : 089531307164 ISSN 2580-1147 (Media Online) 
454 Pengaruh kepemimpinankepala sekolah dan dana bos terhadap prestasi guru - Rita Armaiyetti, Sufyarma Marsidin, Hanif Alkadri

\section{PENDAHULUAN}

Pendidikan memegang peranan penting untuk menjamin kemajuan dan kelansungan hidup bangsa dan Negara karena pendidikan merupakan sarana yang paling tepat untuk meningkatkan dan mengembangkan kualitas sumberdaya manusia (Sabandi, 2013). Oleh sebab itu pendidikan menjadi tanggung jawab bersama pemerintah dan masyarakat baik dalam pembiayaan, tenaga maupun sarana dan prasarana (Sufyarma, Guntama, \& Ningrum, 2019). Bentuk keseriusan pemerintah terhadap pembiayaan pendidikan ini tertuang dalam Undang-Undang Nomor 20 tahun 2003 menyatakan bahwa pendanaan pendidikan merupakan tanggung jawab bersama antara pemerintah, pemerintah daerah dan masyarakat (Republik Indonesia, 2003).

$$
\text { Pembiayaan pendidikan disetiap }
$$

Pendidikan Dasar (SD, SMP, dan SLB) diberikan Pemerintah dalam bentuk dana Bantuan Operasional Sekolah (BOS) . Besaran Dana penyelenggaraan pendidikan pada Pendidikan Dasar Tahun 2019, yaitu: Sekolah Dasar menerima dana BOS sebesar Rp 800.000. (delapan ratus ribu rupiah) kali jumlah peserta didik, SMP, dan SLB menerima Dana BOS sebesar Rp 1.000.000.- (satu juta rupiah) kali jumlah peserta didik untuk satu tahun anggaran berjalan.

Bagi Sekolah Dasar (SD) pembiayaan pendidikan yang bersumber dari dana BOS pengelolaannya oleh Kepala Sekolah, Bendahara BOS, dan Operator komputer (Akbar, 2016). Untuk mengalokasikan dana BOS dalam Rencana Kegiatan Anggaran Sekolah harus dianalisis besarnya dana yang tersedia dengan kebutuhan komponen-komponen yang dibiayai dengan dana BOS.

Komponen-komponen pembiayaan BOS pada Pendidikan Dasar meliputi 11 komponen, yaitu: (1) Pengembangan perpustakaan.
Penerimaan Peserta Didik Baru. (3) Kegiatan pembelajaran dan ekstrakurikuler. (4) Kegiatan evaluasi pembelajaran (Yuliani, 2016). (5) Pengelolaan Pembiayaan Sekolah (Malik, 2014). (6) Pengembangan profesi Guru. (7) Langganan daya dan jasa. (8) Pemeliharaan dan perawatan Sekolah (Hidayat, Burhan, \& Al Ma'ruf, 2019). (9) Gaji honorarium bulanan. (10) Pembelian dan perawatan alat multi media pembelajaran. (11) Biaya lainnya jika seluruh komponen terpenuhi (Silele \& Sabijono, 2017).

Ke sebelas komponen diatas tidak sepenuhnya dapat dibiayai oleh dana BOS karena besarnya biaya yang diperlukan pada beberapa kompenen seperti komponen: (1) Pengembangan perpustakaan. (3) Kegiatan pembelajaran dan ekstrakurikuler.

Kegiatan evaluasi pembelajaran.

Pengembangan profesi Guru. (8) Pemeliharaan dan perawatan Sekolah (Pontoh, Ilat, \& Manossoh, 2017). (9) Gaji honorarium bulanan. (10) Pembelian dan perawatan alat multi media pembelajaran. Hal ini disebabkan karena banyaknya item dari masing-masing komponen, yang menuntut setiap sekolah harus melaksanakannya, sementara dana BOS tidak mencukupi dan sekolah terutama pada Satuan Pendidiana Sekolah Dasar tidak boleh melakukan pungutan kepada siswa, sesuai dengan Permendikbud No.... tahun 2011 tentang larangan pungutan biaya pendidikan pada SD dan SMP, yang tercantum pada Pasal 5 (1) Sekolah yang diselenggarakan oleh masyarakat yang menerima bantuan operasional tidak boleh memungut biaya operasi.

Banyaknya komponen-komponen yang dibiayai dana BOS yang diberikan pemerintah kepada Satuan Pendidikan Sekolah 
Dasar, menyebabkan pembiayaan baru dapat memenuhi standar minimal pendidikan maka Kepala Sekolah bersama Bendahara BOS harus mengupayakan agar dana BOS dioptimalkan penggunaannya membiayai kegiatan penyelenggaraan sekolah. Caranya antara lain dengan menganalisis rencana biaya investasi, biaya operasional, dan biaya personal dengan tepat dan akurat. Untuk itu pihak sekolah terutama Kepala Sekolah harus punya kepiawaian dalam menyikapi dan mengatasi kekurangan dana BOS guna memenuhi standar minimal pendidikan membiayai komponen-komponen kegiatan yang dibiayai BOS (Anggraini, 2013; Fitri, 2014; Mamase, Karim, \& Duda, 2019).

Setelah meninjau dan melakukan observasi di lapangan, rata-rata Sekolah Dasar di Kota Payakumbuh, kekurangan dana BOS dalam memenuhi kebutuhan biaya komponenkomponen tersebut. Data ini peneliti peroleh dari hasil wawancara dan perbincangan dengan sesama Kepala Sekolah dan menanyakan kepada beberapa Pendidik dan Tenaga Kependidikan.

Pada umumnya para Kepala Sekolah Dasar, Pendidik dan Tenaga Kependidikan pengelola dana BOS mengeluh dan merasa kewalahan dalam mengelola dana BOS. Hal ini dipicu begitu banyaknya kegiatan yang akan dan harus dilaksanakan sekolah dalam rangka memenuhi standar minimal pendidikan yang diselenggarakan sekolah, sedangkan dalam penggunaan dana tersebut sekolah diatur dengan petunjuk teknis penggunaan dana BOS dan menyesuaikan dengan Rencana Kegiatan Anggaran Kota (Rifma, Alkadri, \& Ermita, 2019).
Disatu sisi sekolah ingin dan dituntut untuk berprestasi, di sisi lain dana BOS tidak memungkinkan mendukung sepenuhnya program kegiatan sekolah. Kegiatan tidak akan berjalan dengan sempurna apabila dana sekolah tidak mencukupi. Karena muara dari terpenuhinya semua komponen standar minimal pembiayaan adalah prestasi sekolah.

Namun, di sisi lain di beberapa Sekolah Dasar, mereka mampu berprestasi dengan kenyataan kekurangan dana BOS. Oleh karena itu peneliti tertarik untuk melakukan penelitian Pengaruh Kepemimpinan Kepala Sekolah dan Dana BOS terhadap prestasi guru di SDN 61 Kota Payakumbuh.

\section{METODE PENELITIAN}

Penelitian ini merupakan penelitian kualitatif yang bersifat kuantitatif dan korelasi terhadap data yang diperoleh (Creswell, 2016; Sugiyono, 2013). Moleong (2009) meyatakan bahwa penelitian kualitatif adalah penelitian yang bermaksud memahami fenomena tentang apa yang dialami oleh subjek secara holistik dengan cara deskripsi dengan kata-kata dan bahasa pada suatu konteks yang khusus alamiah.Data kualitatif yang dimaksud adalah data yang diperoleh dari lembaran observasi, catatan lapangan, wawancara, dan dokumentasi lainnya.

Lokasi penelitian adalah SD Negeri 61 Kota Payakumbuh Kecamatan Kota Payakumbuh Utara, Kota Payakumbuh, Provinsi Sumatera Barat. Sekolah ini peneliti pilih karena sekolah ini merupakan; Sekolah Inti, Sekolah model, dan Sekolah berprestasi tingkat nasional di bidang Seni. 
Dengan demikian penelitian ini akan mengungkapkan besarnya kontribusi kepemimpinan kepala sekolah dan dana BOS terhadap motivasi prestasi guru. Populasi Penelitian ini adalah semua guru SD Negeri 61 Kota Payakumbuh tahun 2019 dengan jumlah populasi 10 orang.

\section{HASIL DAN PEMBAHASAN}

Penelitian ini dilaksanakan selama dua bulan yang dimulai pada bulan Maret sampai dengan Mei 2020. Data yang didapatkan berdasarkan Informan/observer. Informan penelitian yang digunakan dalam penelitian ini adalah orang-orang sebagai narasumber yang dianggap tahu betul tentang situasi dan kondisi untuk mengungkapkan fakta dilapangan tentang sesuatu permasalahan, seperti yang dijelaskan oleh Moleong (2006 :132) informan adalah orang yang dimanfaatkan untuk memberikan informasi tentang situasi dan kondisi latar belakang penelitian.

Dengan demikian informan penelitian adalah orang yang dianggap menguasai data dan memahami tentang objek penelitian, seperti halnya yang dikatakan Andi (2010:147) bahawa informan adalah orang yang diperkirakan menguasai dan memahami data, informasi, ataupun fakta dari suatu objek penelitian. Informan utama dari penelitian ini adalah semua yang berkaitan langsung di SD Negeri 61 Payakumbuh. Diantaranya adalah Kepala sekolah, dipilih sebagai informan utama atau informan kunci karena sebagai seorang pimpinan disuatu lembaga pendidikan tentunya mengetahui dan menguasai setiap data dan informasi serta bertanggungjawab terhadap seluruh kegiatan pembiayaan pendidikan di sekolah yang dipimpinnya.

Peserta didik merupakan komponen utama terselenggaranya kegiatan pembelajaran. Tanpa peserta didik, proses pembelajaran di sekolah tidak akan terlaksana. Keseluruhan peserta didik yang berjumlah 263 orang menempati 10 kelas yang mengikuti proses pembelajaran di SD Negeri 61 Payakumbuh dengan setiap kelasnya rata-rata berisikan 26 orang peserta didik.

Pendidik merupakan salah satu komponen yang penting dalam menunjang kelancaran proses pembelajaran di sekolah, sedangkan tenaga kependidikan bertugas menunjang penyelenggaraan pendidikan di sekolah. SD Negeri 61 Payakumbuh tahun pelajaran 2019/2020 17 orang pendidik dan tenaga kependidikan, yaitu 1 Orang Kepala Sekolah yang berjenis kelamin perempuan berijazah S1 dan sudah menerima tunjangan sertifikasi, 10 orang guru kelas yang mana 9 orang diantaranya berijazah S1 sementara i orang guru kelas tenaga honorer masih berojazah DII, 3 orang guru mata pelajaran yang terdiri dari 2 orang guru Pendidikan Agama Islam dan 1 orang guru mata Pelajaran Pendidikan Jasmani,Olahraga dan Kesehatan dengan pendidikan $\mathrm{S} 1,1$ orang guru pembimbing khusus tenaga Honorer dengan ijazah S1 PLB , 1 orang tata usaha berijazah S1, dan 1 orang penjaga sekolah laki-laki tenaga honorer yang berijazah SMP .Setiap pendidik dan tenaga kependidikan telah memiliki tugasnya masing-masing yang diatur dalam Surat Keputusan Pembagian Tugas Pendidik dan Tenaga Kependikan. 
457 Pengaruh kepemimpinankepala sekolah dan dana bos terhadap prestasi guru - Rita Armaiyetti, Sufyarma Marsidin, Hanif Alkadri

Sarana dan prasarana sekolah merupakan salah satu komponen yang menunjang keberhasilan proses pembelajaran di sekolah. Ketersediaan sarana dan prasarana yang memadai akan memperlancar kegiatan pembelajaran, sebaliknya sarana dan prasarana yang tidak memadai akan menghambat keberhasilan proses pembelajaran di sekolah.

Untuk tahun pelajaran 2019/2020 ini, di SD Negeri 61 Payakumbuh sudah memiliki ruang belajar yang cukup,ada ruangan belajar 10, ruang Kepala sekolah 1, Ruang majelis Guru 1, Ruang perpustakaan 1, Ruang UKS 1, WC Guru 2, WC peserta didik 6, ruang yang belum memenuhi kriteria adalah ruang UKS, Ruang Bimbingan Khusus, WC Guru dan peserta didik. Baru memanfaatkan ruangan yang ada dan belum memenuhi kriteria standar sarana dan prasarana.

Idealnya SD Negeri 61 Payakumbuh dengan jumlah peserta didik yang cukup banyak dan sebagai SD Inti tempat kegiatan Guru Se Gugus, memerlukan ruang kegiatan peserta didik dan ruang serbaguna/aula, pada tahun 2018 SD Negeri 61 Payakumbuh mendapat bantuan tambahan ruangan 2 kelas dari pemerintah dan batas kelas diganti dengan roling sehingga kelas bisa dijadikan ruang pertemuan.

Bagian temuan khusus dalam deskripsi hasil penelitian ini mengemukakan tentang focus penelitian pada tiga topik mengenai pembiayaan pendidikan di SD Negeri 61 Payakumbuh. Ketiga fokus tersebut adalah 1) Pembiayaan pendidikan di SD Negeri 61Payakumbuh, 2) Bentuk analisis penggunaan dana BOS Sekolah Dasar di SD NEGERI 61Payakumbuh, 3) Pengoptimalan hasil analisis pembiayaan BOS untuk kegiatan penyelenggaraan Sekolah Dasar di SD Negeri 61Payakumbuh. Berikut uraian hasil penelitian yang dideskripsikan berdasarkan hasil penelitian yang telah dilakukan dengan pendekatan kualitatif melalui wawancara, observasi dan dokumentasi.

Hasil penelitian menunjukkan terdapat kontribusi antara kepemimpinan kepala sekolah dengan prestasi guru di SDN Negeri 61 Payakumbuh melalui persamaan garis regresi $=154,03 \mathrm{X} 1$, dengan $\mathrm{F}=5,12$ dan sinifikansi 0,038 $<0,05$. Terdapat korelasi yang signifikan antara kontribusi kepemimpinan kepala sekolah dengan prestasi guru di SD Negeri 61 Payakumbu dengan $r$ hitung $=0,28$, dengan koefesien determinasi sebesar 0,081. Dengan demikian kontribusi kepemimpinan kepala sekolah terhadap prestasi guru sebesar 8,5\%. Sumbangan efektif (SE) kontribusi kepemimpinan kepala sekolah terhadap prestasi guru sebesar $6,9 \%$

Kedua, terdapat kontribusi antara dana BOS dengan prestasi guru di SD Negeri 61 Payakumbuh melalui persamaan garis regresi $=165,282-0,291 \mathrm{X} 2$, dengan $\mathrm{F}=4,698$ dan sinifikansi $0,044<0,05$. Dalam penelitian ini ditemukan korelasi yang signifikan antara kontribusi dana BOS dengan prestasi guru SDN Negeri 61 Payakumbuh dengan $r$ hitung $=0,276$. Dengan koefesien determinasi sebesar 0,076. Dengan demikian kontribusi dana BOS terhadap prestasi guru sebesar 7,8\%. Sumbangan efektif (SE) kontribusi dana BOS terhadap prestasi sebesar $7,42 \%$.

Setiap sekolah pastilah memiliki visi dan misi yang digunakan sebagai pedoman dalam mewujudkan tujuan sekolah masingmasing. Visi dari SD Negeri 61 Payakumbuh adalah "Terwujudnya Peserta Didik Yang beriman, Cerdas, Kreatif dan menerima 
perbedaan". Sedangkan Misi dari SD Negeri

61 Payakumbuh adalah sebagai berikut:

1. Meningkatkan pelaksanaan program Pendidikan Akhlak Mulia di Sekolah

2. Membiasakan peserta didik shalat berjamaah dengan memaksimalkan fungsi masjid yang ada dilingkungan Sekolah

3. Mendorong dan membantu setiap peserta didik untuk mengenali potensi dirinya, sehingga dapat meningkatkan prestasi secara optimal.

4. Mengoptimalkan proses belajar tuntas di setiap tingkat kelas, dengan memberikan jam tambahan di luar jam sekolah.

5. Meningkatkan pengembangan bakat dan minat peserta didik secara optimal melalui kegiatan ekstrakurikuler.

6. Meningkatkan hasil keterampilan dari kreativitas peserta didik setiap tingkat kelas.

7. Meningkatkan rasa kepedulian, berbagi serta cepat tanggap antar sesama peserta didik.

8. Melaksanakan program dan pelayanan individu bagi peserta didik inklusi sesuai dengan sarana dan prasarana yang disediakan Sekolah.

\section{SIMPULAN}

Berdasarkan hasil analisis dan pembahasan, maka simpulan dapat diambil adalah Terdapat kontribusi antara kepemimpinan kepala sekolah dengan kinerja guru di SD Negeri 61 Payakumbuh sebesar $8,5 \%$. . Terdapat kontribusi antara dana BOS dengan prestasi guru di SD Negeri 61 Payakumbuh sebesar $7,8 \%$.

\section{DAFTAR PUSTAKA}

Akbar, M. F. (2016). Evaluasi Kebijakan Program Pemberian Dana Bantuan Operasional Sekolah. Jurnal Analisis Dan Pelayanan Publik.

Anggraini, R. D. (2013). Transparansi , Partisipasi , Dan Akuntabilitas Pengelolaan Anggaran Dana BOS Dalam Program RKAS Di SDN Pacarkeling VIII Surabaya. Kebijakan Dan Manajemen Publik.

Creswell, J. W. (2016). Research Design: Pendekatan Metode Kualitatif, Kuantitatif, Dan Campuran. SAGE Publication.

Fitri, A. (2014). Pengelolaan Dana Bantuan Operasional Sekolah (Bos) Sekolah Dasar Negeri Kecamatan Mandiangin Koto Selayan Kota Bukittinggi. Bahana Manajemen Pendidikan.

Hidayat, R., Burhan, M. R., \& Al Ma'ruf, A. M. (2019). Efektivitas Pengelolaan Dana Bantuan Operasional Sekolah (BOS) Dalam Meningkatkan Sarana Dan Prasarana Pendidikan (Studi Di SDN 44 Mande Kota Bima). JIAP (Jurnal Ilmu Administrasi Publik). Https://Doi.Org/10.31764/Jiap.V7i2.1269

Malik, J. (2014). Sistem Informasi Pengelolaan Dan Laporan Keuangan Dana BOS Berbasis Multi User Di Mts Sudirman Jimbaran. Jurnal Mahasiswa STEKOM Semarang.

Mamase, S., Karim, I., \& Duda, W. (2019). Sistem Informasi Pelaporan Dana Bantuan Operasional Sekolah Berbasis Web. Jurnal Teknologi Informasi Indonesia (JTII). Https://Doi.Org/10.30869/Jtii.V2i1.302

Pontoh, J., Ilat, V., \& Manossoh, H. (2017). Analisis Pengelolaan Dana Bantuan Operasional Sekolah (BOS) Pada Satuan Pendidikan Dasar Di Kota Kotamobagu. JURNAL RISET AKUNTANSI DAN AUDITING "GOODWILL." Https://Doi.Org/10.35800/Jjs.V8i2.18266

Republik Indonesia. (2003). Undang-Undang Sistem Pendidikan Nasional No. 20 
459 Pengaruh kepemimpinankepala sekolah dan dana bos terhadap prestasi guru - Rita Armaiyetti, Sufyarma Marsidin, Hanif Alkadri

Tahun 2003. In Sekretariat Negara. Https://Doi.Org/10.16309/J.Cnki.Issn.100 7-1776.2003.03.004

Rifma, Alkadri, H., \& Ermita. (2019). Supervision Service Practices By School Principals And Impacts Towards The Implementation Of Teacher Duties In Primary Schools. Https://Doi.Org/10.2991/Picema18.2019 .9

Sabandi, A. (2013). Supervisi Pendidikan Untuk Pengembangan Profesionalitas Guru Berkelanjutan. Jurnal Ilmiah Ilmu Pendidikan.

Silele, E., \& Sabijono, H. (2017). Evaluasi Pengelolaan Dana Bantuan Operasional Sekolah (BOS) (Studi Kasus Pada SD Inpres 4 Desa Akediri Kecamatan Jailolo Kabupaten Halmahera Barat). Jurnal Riset Ekonomi, Manajemen, Bisnis Dan Akuntansi.

Sufyarma, Guntama, N. B., \& Ningrum, T. A. (2019). The Management Of Students Character Building In Senior High School. Https://Doi.Org/10.2991/Picema18.2019 .38

Sugiyono. (2013). Metode Penelitian Pendidikan Pendekatan Kuantitaif, Kualitatif, Dan R\&D. Metode Penelitian Pendidikan Pendekatan Kuantitaif, Kualitatif, Dan $R \& D$. Https://Doi.Org/10.1007/S13398-0140173-7.2

Yuliani, H. (2016). PEMBIAYAAN PENDIDIKANDI SEKOLAH DASAR NEGERI NGROJO. Jurnal Hanata Widya. 